\title{
Validation of the Polyacrylic acid/Glassy Carbon Differential Pulse Anodic Stripping Voltammetric Sensor for Simultaneous Analysis of Lead(II), Cadmium(II) and Cobalt(II) Ions
}

\author{
Moses O. Oyagi, John O. Onyatta, Geoffrey N. Kamau, Peterson M. Guto* \\ Department of Chemistry, University of Nairobi, P. O. Box 30197, Nairobi, Kenya \\ *E-mail: Peterson.guto@uonbi.ac.ke
}

doi: $10.20964 / 110386$

Received: 19 January 2016 / Accepted: 22 February 2016 / Published: 1 April 2016

\begin{abstract}
Electrochemical sensor validation ensures that the determination procedure employed for a specific test is suitable for its intended use. Accuracy and precision, linearity, range, limits of detection and quantification validation parameters were determined for the Polyacrylic acid/Glassy Carbon Differential Pulse Anodic Stripping Voltammetric Sensor used for the simultaneous analysis of $\mathrm{Pb}(\mathrm{II})$, $\mathrm{Cd}(\mathrm{II})$ and $\mathrm{Co}(\mathrm{II})$ in accordance with the guidelines of the ISO/IEC 17025. The recovery degree for accuracy were in the range of $101 \%$ to $110 \%$ for $\mathrm{Pb}(\mathrm{II}), 100 \%$ to $105 \%$ for $\mathrm{Cd}(\mathrm{II})$ and $93 \%$ to $104 \%$ for Co(II). The precision was found to be less than $10 \%$ for ten determinations. Linear concentration range were also investigated and found to lie in the range of $125-7.8 \mu \mathrm{M} \mathrm{Pb}(\mathrm{II}), 16-2 \mu \mathrm{M} \mathrm{Cd}(\mathrm{II})$ and $2-0.125 \mathrm{mM} \mathrm{Co}(\mathrm{II})$. Limits of detection also were found to be $0.9 \mathrm{nM} \mathrm{Pb}, 1.9 \mathrm{mM} \mathrm{Cd}$ and $11.0 \mu \mathrm{M} \mathrm{Co}$ and limits of quantitation were $3.0 \mathrm{nM} \mathrm{Pb}, 6.3 \mathrm{nM} \mathrm{Cd}$ and $36.7 \mu \mathrm{M} \mathrm{Co}$. The effects of foreign substances like $\mathrm{Cu}^{2+}, \mathrm{SO}_{4}{ }^{2-}, \mathrm{K}^{+}, \mathrm{Na}^{+}, \mathrm{Cl}^{-}, \mathrm{NH}_{4}^{+}$and $\mathrm{O}_{2}$ were found to have no significant effect on the electrochemical responses of the three heavy metals. These results confirms that this sensor can provide accurate, reliable and consistent results for the determination of $\mathrm{Pb}(\mathrm{II}), \mathrm{Cd}$ (II) and $\mathrm{Co}$ (II) heavy metals in diverse samples.
\end{abstract}

Keywords: Validation, Polyacrylic acid/Glassy carbon electrode, Lead, Cadmium, Cobalt and differential pulse anodic stripping voltammetry.

\section{$\underline{\text { FULL TEXT }}$}

(C) 2016 The Authors. Published by ESG (www.electrochemsci.org). This article is an open access article distributed under the terms and conditions of the Creative Commons Attribution license (http://creativecommons.org/licenses/by/4.0/). 